\title{
Management Science Letters
}

The influence of Tudang Sipulung, public accountability, and transparency to the regional budget performance of the municipality of Parepare

\section{Yadi Arodhiskara $^{a^{*}}$, Masdar Mas'ud ${ }^{b}$, Muhammad Su'un $^{\mathrm{b}}$ and Mursalim ${ }^{\mathrm{b}}$}

${ }^{a}$ Universitas Muhammadiyah Parepare, Indonesia

${ }^{b}$ Universitas Muslim Indonesia, Indonesia

\section{H R O N I C L E}

\section{Article history:}

Received: July 7, 2020

Received in revised format:

August 102020

Accepted: August 17, 2020

Available online:

August 25, 2020

\section{Keywords:}

Tudang Sipulung

Public Accountability

Transparency

Budget Performance

\section{A B S T R A C T}

The purpose of this study is to analyze and find out the influence of the Tudang Sipulung, public accountability and transparency on budget performance in the Regional Government of Parepare. Respondents in this study were 102 employees of the Regional Government of Parepare. The analytical model used to determine the effect between variables is a structural model with the Partial Least Square (PLS) approach. The results show that Tudang Sipulung had no significant effect on Budget Performance, Public Accountability had a significant effect on Budget Performance, and Transparency had no significant effect on the Budget Performance. This means that the implementation of the Tudang Sipulung and transparency has not been optimal in seeing the performance of the budget, in contrast to public accountability which is considered quite good. To improve the performance of the budget, it is good for the regional government to be open starting from the planning process to reporting, creating good management and open to all information.

(C) 2021 by the authors; licensee Growing Science, Canada

\section{Introduction}

Budget is a very important aspect in a company. In addition to functioning as a financial planning tool designed for the purpose of measuring company costs and revenues, the budget also acts as a tool for control, coordination, communication, motivation and managerial performance appraisal (Izzetin, 1979; Dewi et al., 2019). The existence of a budget will encourage organizational sustainability. The Regional Government of Parepare as one of the public sector entities in using its authority determines the budget. The following is shown Local Government Budget (APBD) data in Parepare in Table 1 as follows:

Table 1

Local Government Budget (APBD) in Parepare 2011-2019

\begin{tabular}{ccc}
\hline Year & APBD Budget (Rupiah) & Percentage (\%) \\
\hline 2011 & $475.730 .775 .008,68$ & $7,26 \%$ \\
2012 & $516.129 .069 .922,64$ & $7,87 \%$ \\
2013 & $475.028 .825 .622,14$ & $7,24 \%$ \\
2014 & $594.621 .694 .031,00$ & $9,07 \%$ \\
2015 & $620.172 .032 .847,00$ & $9,46 \%$ \\
2016 & $788.946 .115 .619,38$ & $12,04 \%$ \\
2017 & $1.052 .521 .386 .871,00$ & $16,06 \%$ \\
2018 & $1.002 .041 .393 .978,00$ & $15,29 \%$ \\
2019 & $1.027 .092 .428 .827,45$ & $15,67 \%$ \\
\hline
\end{tabular}

* Corresponding author.

E-mail address: aroxyadi@gmail.com (Y. Arodhiskara) 
While the absorption of the regional budget in Parepare is said to be still low. Head of the Regional Budget Agency (BKD) Parepare said, Local Government Budget (APBD) in 2017 reached more than Rp 1 trillion, but until now the budget absorption for direct expenditure has only reached 8.51 percent or approximately 9 percent. Meanwhile, indirect expenditure added with new salary was 13.22 percent, meaning that salary expenditure and indirect expenditure were higher than direct expenditure. The Head of the Local Development Planning Agency (Bappeda) of Parepare explained, The low level of budget absorption is due to the slow implementation of activities in each Local Government Work Unit (SKPD). Due to the low level of budget absorption in each Local Government Work Unit (SKPD) of the Parepare, the local government implements a performancebased budget in the preparation of the budget. With the implementation of performance-based budgeting, it is expected that the budget prepared by the government can be realized properly in accordance with the goals and objectives to be achieved by the government. Performance measurements conducted by local governments will make development programs more targeted and timely, one of the performance measures currently being developed is the Value For Money (VFM) approach. Performance measurements carried out by local governments will make development programs more targeted and timely, one of the measurements according to Mardiasmo (2009), Value for Money is the concept of managing public sector organizations based on three main elements, namely economic, efficient, and effectiveness". The use of the Value for Money principle can be used as a basis for improving public sector budgets. The existence of a number of cases of poor budget management, indicating that the implementation of budgeting in the public sector must be based on the implementation of accountability, transparency and the principle of Value for Money. Previous research on topics such as Caleb and Godwyns (2012) shows a relationship between good governance and good budgeting. Meanwhile, Kiase and Dougherty (2008) note that the implementation of budgeting performance has a significant influence on budget results as reflected in per capita expenditure. According to Andrews and Hill (2003), budget performance can improve the efficiency of public service delivery and government services and increase public confidence in the government.

One form of the implementation of non-formal budgetar participation held in Parepare is Tudang Sipulung. Sipulung Tudang is a traditional communication medium of South Sulawesi in the form of sitting together or deliberations between the government and the community to get input in order to formulate programs and policies that will be implemented in each subsector that is supported and enhanced

The Tudang Sipulung theory used by Takko and Mukhlis (2001) explains that the Tudang Sipulung is culturally related to the problem of public or community space to voice their interests in order to find solutions to the problems they face. This means that the Tudang Sipulung is a space that can mediate between the interests of the public and the government (authority) because it takes place based on democratic principles.

Public accountability according to Mahmudi (2015) states that public accountability is the main foundation for the process of good governance. Therefore the government apparatus must account for all activities and work performance to the public public. Apart from public accountability factors that affect budget performance, transparency also has an influence on budget performance. In budget management, if it is more transparent, it will be easier to access information, so that the public can participate in monitoring and overseeing budget management. Therefore the higher the transparency, it will increase the performance of the budget based on value for money.

\subsection{Research Problem}

1. What is the effect Tudang Sipulung on the Regional Budget Performance of the Municipality of Parepare ?

2. What is the effect accountability on the Regional Budget Performance of the Municipality of Parepare?

3 What is the effect transparency on the the Regional Budget Performance of the Municipality of Parepare?

\section{Literature Review}

\subsection{Tudang Sipulung}

Tudang Sipulung, in the Bugis Makassar language, can literally be interpreted, sitting together, namely tudang (sitting) and sipulung (gathering or together), but if it is related to the problem of governance relations or citizenship, then culturally politically it is related to the issue of public space or space for the public (the people) to voice their interests in order to find solutions to the problems they face. This means that the Tudang Sipulung is a space that can mediate between the interests of the public and the government (the authorities) because it takes place based on democratic principles.

An understanding of the concept of the Bugis Makassar public sphere, cannot be separated completely from the context of traditional values that are still held and recognized by the majority of the people of South Sulawesi until now. The customary values which form the legal and philosophical basis of life are Ade '(adat). Ade', for most of the people of South Sulawesi, is a cultural personality (Abdullah, 1985), because adat is the driving force of a community's life. A similar was also conveyed by Mattulada, that custom is what gives its shape in the form of the character of society and culture and the people who support it (Mattulada, 1974). In line with the opinion of Yasin et al., (2019) That it is an obligation to keep preserving the cultural heritage of ancestors. 
Tudang Sipulung is a traditional public space for the Bugis Makassar community to express their aspirations on the issues of governance, and seek agreement (common will) on the issues being faced. The decision taken in the Tudang Sipulung must be based on the principle of massolo 'pao (flowing together), which means that the decision to be reached in sitting together (deliberation) is a decision of the common will and for the common interest, which is likened to water flowing together. That is, the will of the ruler (royal government) and the will of the people must go hand in hand in finding common ground based on mutual interests

\subsection{Public Accountability}

Accountability can be interpreted as a form of accountability must require or ask for predetermined accountability, through a media of accountability that is run periodically. The definition of public accountability according to Lukito (2014) is as follows: Accountability is a form of obligation for providers of public activities to be able to explain and answer all matters relating to the steps of all decisions and processes carried out, as well as accountability for the results of their performance. Meanwhile according to Mahmudi (2013) public accountability is as follows: Obligations of Agents (Government) to manage resources, report, and disclose, all activities and activities related to the use of public resources to the mandate giver. According to Bastian (2010) public accountability is as follows: public accountability is an obligation to convey accountability or to answer, explain the performance, and actions of a person or legal entity and collective leadership or organization to parties who have the right or authority to request information or accountability. All decisions and processes are carried out, as well as accountability for the results of its performance. The definition of accountability according to Lloyd, et al in Ebrahim (2010) is as follows: The process by which an organization makes a commitment to respond to and balance the needs of stakeholders in the decision making process and its activities, and fulfill this commitment. The wider community as an objective assessor who will determine the accountable include the following

a. Able to present information about government operations openly, quickly and precisely to the public.

b. Able to provide satisfying services for the public.

c. Able to explain the space for the community to be involved in the development and governance process.

d. There is a target for the public to assess performance

\subsection{Transparency}

Government theory explains transparency is a principle that guarantees access or freedom for everyone to obtain information about the administration of government, namely information about policies, the process of making, implementing, and the results achieved. Understanding Financial Transparency according to Government Accounting Standards (2005) states that transparency provides financial information that is honest and open to the public based on the consideration that the public has the right to openly and comprehensively know about government responsibilities in managing resources. entrusted to it. and compliance with laws and regulations. According to Meutiah (2008) Transparency is an open policy for supervision. Whereas what is meant by information is information about every aspect of government policy that can be reached by the public. Information disclosure is expected to produce healthy, tolerant political competition and policies based on public references. This principle has 2 aspects:

a. Public communication, and

b. Community rights to access information.

\subsection{Budget Performance}

According to Mardiasmo (2009), the budget is a statement about the estimated performance to be achieved during a certain period of time expressed in financial measures, while budgeting is a process or method for preparing a budget. A budget is a statement of the estimated performance that will be achieved during a certain period and expressed in financial measures. Regional financial reforms are associated with changes in local government funding sources which include changes in revenue sources. Budget reform is not only in the aspect of changes in the structure of the Local Government Budget (APBD), but also followed by changes in the budget preparation process. Local Government Budget (APBD) in the era of regional autonomy is prepared with a performance approach. Budget performance system concept of Value for money or performancebased budgeting is a budget system that prioritizes efforts to achieve the results of work or output from the planned cost or input allocation (Bastian, 2010). From this definition it can be concluded that performance-based budgeting is more effective than program or organizational budgets with anticipated outcomes, because this system explains the relationship of costs (Rp) to results (results), so it can be said that this system deals effectively with a program. With a performance based budgeting system, government dominance can be monitored and controlled through the implementation of internal cost awareness, financial audits, performance audits, and external performance evaluations. With a performance based budgeting system, government dominance can be monitored and controlled through the implementation of internal cost awareness, financial audits, performance audits, and external performance evaluations. The development of performance indicators focuses on the economy, efficiency, and effectiveness of programs and activities, known as 3E. Economical means saving and careful in the procurement and allocation of resources, efficient means efficient in the use of resources for maximum results, and effective. 


\subsection{Conceptual Framework}

Fig.1 shows the framework of the proposed study of this paper.

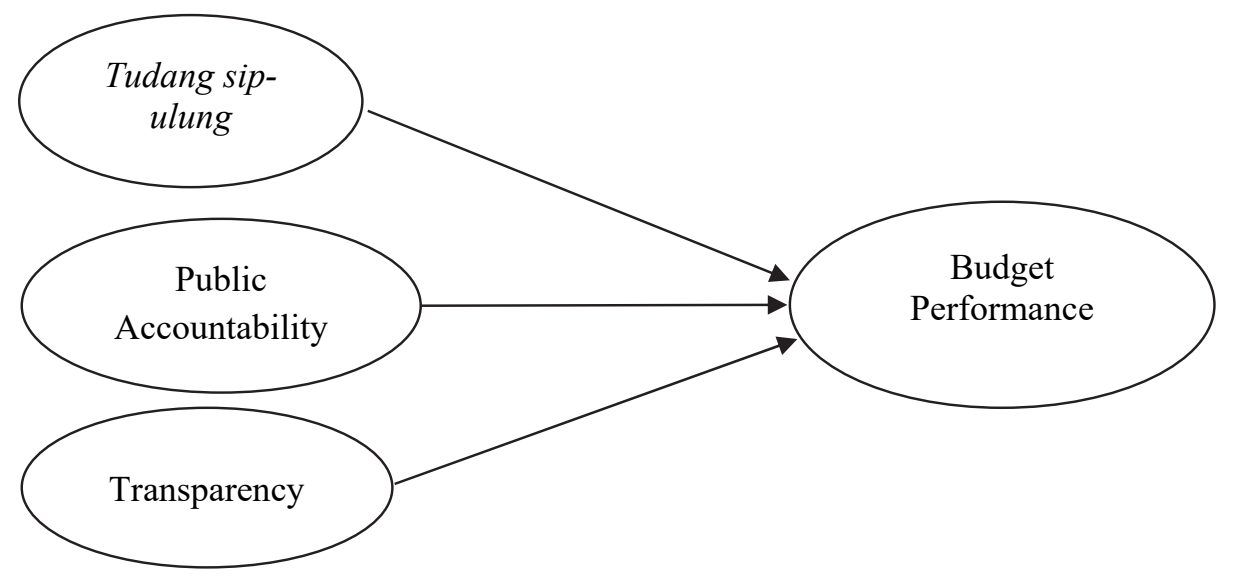

Fig. 1. Concept Framework

Referring to the formulation of the problem and previous research that has been presented before, the proposed hypothesis is as follows:

$\mathrm{H}_{1}$ : Tudang Sipulung significantly influences the Budget Performance.

$\mathrm{H}_{2}$ : Public Accountability has a significant effect on Budget Performance.

$\mathrm{H}_{3}$ : Transparency has a significant effect on Budget Performance.

\section{Research methods}

\section{1. Research Location}

This research was conducted at the Regional Government Organization (OPD) of the municipal government of Parepare, South Sulawesi Province.

\subsection{Population and Samples}

The population in this study were 536 employees. Furthermore, to count the number of samples using probability sampling with a purposive random sampling method.

Table 2

The number of respondents is based on employee strata in the Regional Government Organization (OPD) of Pare-Pare Municipality

\begin{tabular}{cccc}
\hline Echelon & Total Population & Sample Calculation & Total Samples \\
\hline II-A & 1 & $(1 / 536) \times 100$ & 1 \\
II-B & 17 & $(17 / 536) \times 100$ & 3 \\
III-A & 35 & $(35 / 536) \times 100$ & 7 \\
III-B & 63 & $(63 / 536) \times 100$ & 12 \\
IV-A & 319 & $(101 / 536) \times 100$ & 60 \\
IV-B & 101 & & 19 \\
JUMLAH & 536 & & 102 \\
\hline
\end{tabular}

Source : Regional Organization of Parepare

\subsection{Data Analysis Methods}

Data collection techniques (instruments) used were a questionnaire, interview, and document search. The data analysis method used in this study is data analysis using SmartPLS software. PLS (Partial Least Square) is a variance-based structural equation analysis (SEM) that can simultaneously test measurement models as well as structural model testing. The measurement model 
is used to test the validity and reliability, while the structural model is used to prove causality (hypothesis testing with predictive models). Furthermore, Rigdon et al. (2017) explained that PLS is an analysis method that is soft modeling because it does not assume the data must be with a specific scale measurement, which means the number of samples can be small (under 100 samples). The fundamental difference between PLS, which is an SEM-based variant with LISREL or AMOS is covariant based. Compared with covariance-based SEM (represented by AMOS, LISREL and EQS software) based components are PLS able to avoid the two major problems faced by covariance-based SEM, namely inadmissible solution and indeterminacy factor (Hair et al., 2017).

\section{Research Results}

\subsection{Measurement Model (Outer Model)}

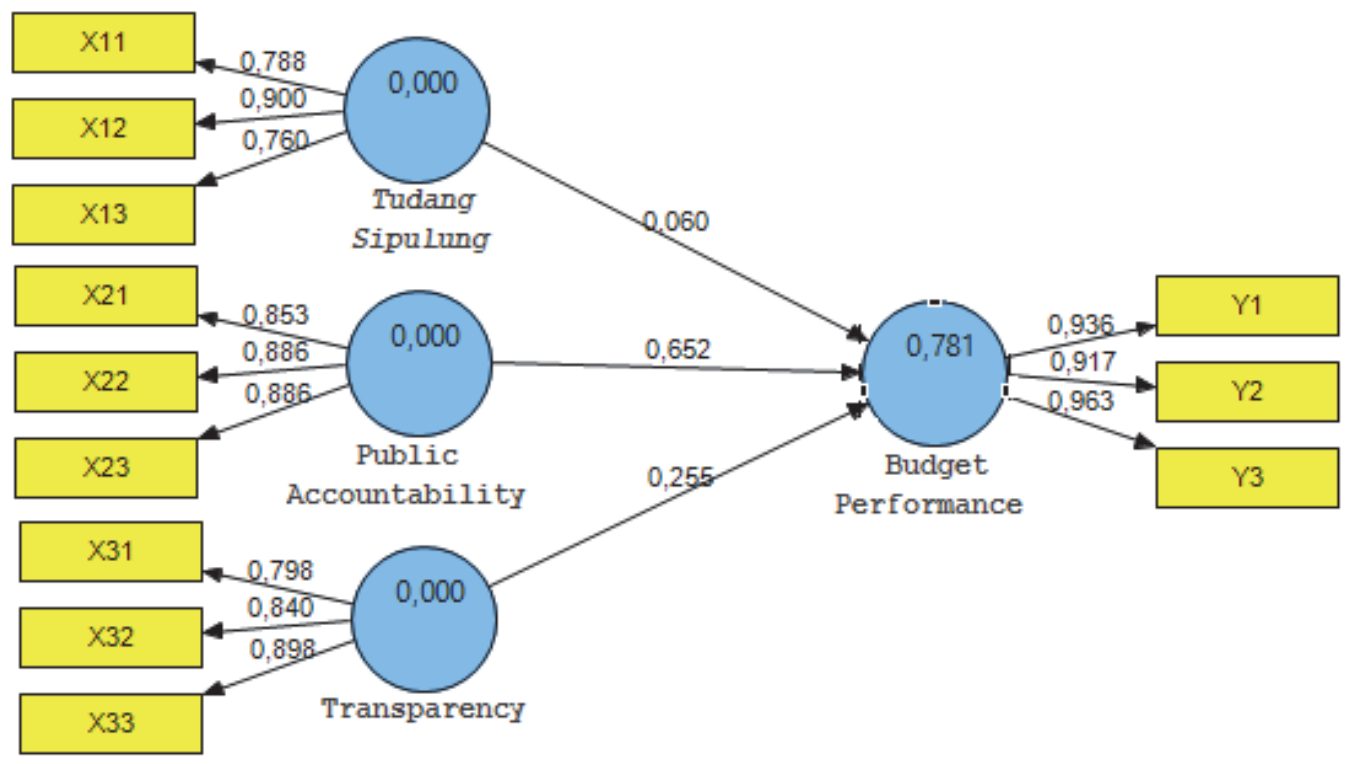

Fig. 2. SEM-PLS Measurement Model (Outer Model)

The construct of the Tudang Sipulung, public accountability, transparency and budget performance are analyzed by looking at the convergent validity and reliability of each indicator. The output in Table 3 and Fig. 2 below shows the loading factor for the four constructs above 0.5 required, with a statistical $\mathrm{T}$ value above 1.96 (for a significance level of 0.05 ) indicating that the construct has discriminant validity the good one.

Table 3

Outer Loadings (Mean, STDEV, T-Value)

\begin{tabular}{lcccc}
\hline & $\begin{array}{c}\text { Original } \\
\text { Sample (O) }\end{array}$ & $\begin{array}{c}\text { Sample } \\
\text { Mean (M) }\end{array}$ & $\begin{array}{c}\text { Standard Deviation } \\
\text { (STDEV) }\end{array}$ & $\begin{array}{c}\text { T Statistics } \\
(\mathbf{O O} / \mathbf{S T E R R})\end{array}$ \\
\hline Honest deeds (X11) & 0,788461 & 0,786799 & 0,042880 & 18,387461 \\
\hline Constancy (X12) & 0,900168 & 0,895677 & 0,022884 & 39,335265 \\
Respect (X13) & 0,760477 & 0,759283 & 0,062932 & 12,084173 \\
\hline Accountability for probity (X21) & 0,853431 & 0,849259 & 0,039073 & 21,842077 \\
Process accountability (X22) & 0,886196 & 0,880162 & 0,036245 & 24,450128 \\
\hline Liability (X23) & 0,885654 & 0,885689 & 0,021629 & 40,947494 \\
\hline Provision of clear information about the procedure (X31) & 0,797841 & 0,803471 & 0,024540 & 32,512263 \\
\hline Easy access to information (X32) & 0,840193 & 0,827165 & 0,059797 & 14,050653 \\
\hline Increasing the flow of information through collaboration with mass & 0,897838 & 0,888171 & 0,043770 & 20,512799 \\
media and non-government institutions (X33) & 0,935944 & 0,934398 & 0,020586 & 45,464430 \\
\hline Economic Measurement (Y1) & 0,916886 & 0,914918 & 0,023901 & 38,362365 \\
\hline Effectiveness Measurement (Y2) & 0,962757 & 0,962000 & 0,010764 & 89,438649 \\
\hline Outcome Measurement (Y3) & & & & \\
\hline Source: PLS & & &
\end{tabular}

Source : PLS data processing (2020) 
4.2 Testing the Structure Model (Inner Model.)

Table 4

$\underline{\text { R-Square dan Cronbachs Alpha }}$

\begin{tabular}{|c|c|c|c|c|}
\hline & AVE & $\begin{array}{c}\text { Composite } \\
\text { Reliability (CR) }\end{array}$ & R Square & $\begin{array}{l}\text { Cronbachs } \\
\text { Alpha (CA) }\end{array}$ \\
\hline Tudang Sipulung & 0.670099 & 0.858368 & & 0.750848 \\
\hline Public Accountability & 0.766024 & 0.907569 & & 0.847673 \\
\hline Transparency & 0.716196 & 0.883081 & & 0.808050 \\
\hline Budget Performance & 0.881191 & 0.956974 & 0.781174 & 0.932375 \\
\hline
\end{tabular}

Source : PLS data processing (2020)

Discriminant reliability (AVE), Cronbach alpha (CA), and composite composites (CR) were measured. The criteria state that if discriminant reliability (AVE) is greater than 0.5 , Cronbach alpha is greater than 0.6 and composite reliability is greater than 0.7, the construct is declared reliable. The reliability test shows (Table 4) that all latent constructs have AVE values greater than 0.5 , CA values greater than 0.6 , and $\mathrm{CR}$ values greater than 0.7 . Therefore, based on reliability criteria, all items can be declared reliable in measuring latent variables. R-square Model of Tudang Sipulung measurement, public accountability, transparency on performance budget is 0.781 or $78.1 \%$. which can be interpreted that the influence of the variable Tudang Sipulung, public accountability, transparency on budget performance is $78.1 \%$.

Table 5

Path Coefficients (Mean, STDEV, T-Values)

\begin{tabular}{cccccc}
\hline & $\begin{array}{c}\text { Original SampIle } \\
(\mathbf{O})\end{array}$ & $\begin{array}{c}\text { Sample Mean } \\
(\mathbf{M})\end{array}$ & $\begin{array}{c}\text { Standard } \\
\text { Deviation } \\
\text { (STDEV) }\end{array}$ & $\begin{array}{c}\text { T Statistics } \\
(\mid \mathbf{O} / \text { STDEV|) }\end{array}$ & $\begin{array}{c}\text { Information } \\
\text { Tudang Sipulung } \rightarrow \text { Budget Performance }\end{array}$ \\
\hline Public Accountability $\rightarrow$ Budget Performance & 0,059658 & 0,061325 & 0,104118 & 0,572983 & No Signifikan \\
\hline Transparency $\rightarrow$ Budget Performance & 0,652487 & 0,645887 & 0,090517 & 7,208425 & Signifikan \\
\hline
\end{tabular}

Source : PLS data processing (2020)

The next test is to test the hypothesis and determine the significance of the influence of exogenous variables on endogenous variables. SEM-PLS explains that the hypothesis measures significance by comparing T-table and T-statistic values. If the $\mathrm{T}$ Count statistic is higher than the T-table value, then the hypothesis is accepted. The 95 percent confidence level (or 5\%; $<0.05$ ) for the two-sided hypothesis is $>1.96$.

Table 5 answers the following hypotheses:

1. Tudang Sipulung has no significant effect on the Budget Performance

2. Public Accountability has a significant effect on Budget Performance

3. Transparency does not significantly influence the Budget Performance

\section{Discussion}

\subsection{Tudang Sipulung has no significant effect on Budget Performance}

The results showed that Tudang Sipulung did not significantly influence the Budget Performance. The results of research on Tudang Sipulung in this case the involvement of the community in involving them in determining programs that use regional budgets does not always show that the management of these funds is good, This was stated by one of the employees who stated that community involvement was not a priority because in the end the regional apparatus would determine what program decision to choose. Conversely, if the management of regional budgets does not involve the community, programs that use local budgets will continue to run. The Local Government proves by inviting the community to carry out programs such as building roads, when the local government invites the community into development activities, many people refuse on the grounds that there is already a budget to build the road, so community involvement in the implementation does not always indicate that the budget management has been carried out well, and vice versa, the lack of involvement of the community in the implementation process does not always indicate that budget management is bad. The results of this study refer to the benefit-taking that the program chosen with the community in the Tudung Sipulung must refer to the needs of the community and be effective for the welfare of the community. Community involvement in evaluating budget management can be said to be lacking or non-existent. The involvement of the Tudang Sipulung variable only reaches the stage of proposals about what is really needed by them, so that the government can fulfill and prioritize what the community needs. 


\subsection{Public Accountability has a significant effect on Budget Performance}

The results of this study indicate that every policy in managing the budget has been well accounted for by the Municipality of Parepare. The performance of the Government of Parepare to the public can be seen from the compliance of preparing reports on budget realization in a timely and truthful manner. and the influence or reciprocity of the results of budget management that can be felt directly by the community. In addition, Parepare Government's compliance with procedures and law will also encourage the creation of a government that is free of corruption. Therefore, it is expected that the Parepare Government will always comply with procedures and laws, as well as being accountable in managing the budget. This research is in line with the research conducted by Fernandes et al. (2015), states that Accountability has a positive and significant effect on the management of the concept of value for money.

\subsection{Transparency does not significantly influence the Budget Performance}

The results of this study are supported by the results of previous studies such as research conducted by Sangki et al. (2016) whose research results show that there is no transparency about the government-managed budget so that the general public does not know the Local Government Budget (APBD) detail. Transparency does not even have a positive impact or influence on governance in Parepare and the openness of the government in making policies unknown to the public. Increasing transparency of an entity will also increase the performance of the budget. In response to demands for transparency that are regulated by law, the Government of Parepare must be able to expose the existing mass media, both print and electronic. This is because transparency is built on the basis of freedom to obtain information needed by the community, information relating to the public interest must be directly obtained by those who need it. When people get information related to an agency's performance, it can be assumed that public trust in the agency can be formed. Based on the results of the study, it was found that the public was not able to access public documents transparently, this was due to the government's delay in presenting these documents, so that people had difficulty in accessing public documents.

\section{Conclusion}

Regional government openness should start from planning to reporting in an open manner to maintain a positive relationship between the government and the community. To create good management, disclosure of information will enable the community to assess the performance of local governments in managing local budgets. The results of research in terms of community involvement through the Tudang Sipulung media should start from the management process, both planning and reporting, community involvement through the Tudang Sipulung media is expected to provide convenience for local governments in determining priorities for using the budget, community involvement will also make the community active in activities, eisting activities, since this shows that the local government gives accountability to the community. The government must also be transparent about financial information, although there is still much to be improved and improved, and the local government must also be able to involve community representatives in decision-making even though there is still little contribution from the community.

\section{References}

Abdullah, H. (1985). Manusia Bugis Makassar: suatu tinjanuan historis terhadap pola tingkah laku dan pandangan hidup manusia Bugis Makassar. Inti Idayu Press.

Andrews, M., \& Hill, H. (2003). The impact of traditional budgeting systems on the effectiveness of performance-based budgeting: a different viewpoint on recent findings. International Journal of Public Administration, 26(2), $135-155$.

Bastian, I. (2010). Akuntansi Sektor Publik Suatu Pengantar Edisi Ketiga. Jakarta: Erlangga.

Caleb, B., \& Godwyns, A. (2012). Good Budgeting and Good Governance: A Comparative Discourse. Departement of Accounting, School of Business.

Dewi, N., Azam, S., \& Yusoff, S. (2019). Factors influencing the information quality of local government financial statement and financial accountability. Management Science Letters, 9(9), 1373-1384.

Ebrahim, A. (2010). The Many Faces Of Non Profit Accountability. Haarvard Business School.

Fernandes, W., Kennedy, K., \& Hanif, R. A. (2015). Pengaruh Akuntabilitas, Transparansi dan Pengawasan terhadap Kinerja Anggaran pada Pemerintah Daerah Kabupaten Kampar (Doctoral dissertation, Riau University).

Hair, J. F., Hult, G. T. M., Ringle, C. M., \& Sarstedt, M. (2017). A Primer on Partial Least Squares Structural Equation Modeling (PLS-SEM) (2nd Edition). Thousand Oaks: Sage Publications, Inc.

Izzetin, K. (1979). Effect of Budgetary Goal Characteristics on Managerial Attitutes and Performance. The Accounting Review, 14(4), 172-189.

Kiase, K. A., \& Dougherty, M. J. (2008). The impact of performance budgeting on state budget outcomes. Journal of Public Budgeting, Accounting \& Financial Management, 20(3).

Lukito, P. K. (2014). Membumikan transparansi dan akuntabilitas kinerja sektor publik: Tantangan berdemokrasi ke depan. Grasindo (PT Gramedia Widiasarana Indonesia).

Mahmudi (2015). Manajemen Kinerja Sektor Publik Edisi Kedua.Yogyakarta: UPP STIM YKPN.. 
Mardiasmo (2009). Akuntansi Sektor Publik, Andi, Yogyakarta.

Mattulada, A. (2014). Manusia dan Kebudayaan Bugis-Makassar dan Kaili di Sulawesi. Antropologi Indonesia.

Meutiah Ganie Rochman. (2008). Perubahan Pemerintah: Good Governance.

Rigdon, E. E., Sarstedt, M., \& Ringle, C. M. (2017). On comparing results from CB-SEM and PLS-SEM: Five perspectives and five recommendations. Marketing Zfp, 39(3), 4-16.

Sangki, A. A., Gosal, R., \& Kairupan, J. (2017). Penerapan Prinsip Transparansi Dan Akuntabilitas Dalam Pengelolaan Anggaran Pendapatan Dan Belanja Desa (Suatu Studi Di Desa Tandu Kecamatan Lolak Kabupaten Bolaang Mongondow). Jurnal Eksekutif, 1(1).

Takko, A.B \& Mukhlis, H. (2001). Hak Asasi Manusia dalam Budaya Bugis, Laporan Hasil Penelitian Rutin. Makassar: Lembaga Penelitian Unhas

Yasin, N. A., Ridjal, S., \& Jjufri, M. (2019). Human capital and entrepreneurship and their impact on the productivity of traditional craftsmen. Revista ESPACIOS, 40(04), 8-20.

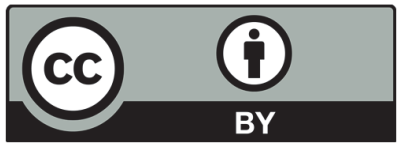

(C) 2020 by the authors; licensee Growing Science, Canada. This is an open access article distributed under the terms and conditions of the Creative Commons Attribution (CC-BY) license (http://creativecommons.org/licenses/by/4.0/). 